\title{
Coming Home after the Surge: Dissecting The Heart of the Matter Report from The American Academy of Arts \& Sciences
}

\author{
Timothy W. Luke
}

\section{Overview}

This brief statement is a meditation on mystification. At this moment, the United States of America is beset by crises, contradictions, and conflicts. It remains engaged in long-running undeclared wars. Voter turnout for many local, state, and national elections is abysmal. Corporations are officially recognized as legal persons with definite basic rights. Much of civil society escapes daily into the cybernetic haze of social media. The deep state has virtually everyone under some sort of surveillance. Now many members of the armed forces, once deployed overseas have been returning home after "the surge" in Iraq and Afghanistan, but remain wary of a recall to new deployments in Syria, Libya or Yemen. At this same conjuncture of events, however, an august group of academicians, artists, and activists recently joined a few other experts, while averting their eyes from these disasters, to write a national report about the declining condition of the arts and sciences that America's citizens need to assess these disastrous events in their public and private lives.

Coming together as the Commission on the Humanities and Social Sciences, they produced a substantial white paper--The Heart of the Matter: The Humanities And Social Sciences for a Vibrant, Competitive, and Secure Nation--to extoll the national need to strengthen the humanities and social sciences at all educational levels. This bold move, they assert, would brighten America's already gleaming greatness. Learning more about the work of humanists and social scientists, according to the Commission, might help American citizens better participate more "meaningfully in the democratic process--as voters, informed consumers, and productive workers" (The Heart of the Matter [hereafter HM], 2013:10), and thereby rise above the nation's current political malaise. Yet, they ignore, at the same time, the complex social forces whose influences neutralize collective power, estrange citizens in voting, and rob the country of good jobs needed for voters to be "informed buyers" in today's purportedly liberal democratic capitalism. Mystification then is indeed flowing through many aspects of this Commission's activities.

Because this report's writers appear to have, as Marx notes, "accepted its language and its laws," the market strictures of today's globalized political economy dominate the Commission's analysis, exposing how nakedly "the increasing value of the world of things proceeds in direct proportion to the devaluation of the world of men" (Marx, 1978: 70, 71). Washington's inclination since 2000 to put the stability of insurance companies, money center banks, and equity markets at the heart of America's public policy matters suggests those elite institutions are valued far more than ordinary men and women. Even so, the Commission asserts more humanistic learning and social scientific research could make full amends for these troubles.

In actuality, The Heart of the Matter report implicitly concurs with Marx. The more citizens participate under the influences of a false consciousness derived from nonhumanistic learning or unsocial nonscientific teaching, the 
desultory voter, uninformed consumer, and unproductive worker put what little life they have into the objectified routines of empty formalized democratic processes. Plainly, each citizen tacitly concedes the product of his/her civic agency and economic praxis is "an alien object" in which their lives no longer belong to them but rather "to the object" (Marx, 1978: 72).

From the perspective of critical new political scientists, the key mystification that one must confront here, at root, is scholastic simplicity. The Commissioners make a naïve claim: if all citizens could think better (due to having more humanities and social sciences knowledge), then our world will improve due to such improved thinking. Standing on this thin ice, the Commission issues a spirited call to arms. It is not a radical question, like "What must be done?" but rather an estranged, nationalist, and elitist plea "Who will lead America into a bright future?" (HM, 2013: 4). That America now can even be led, that a bright future beckons it, and that historical agents await awakening from their slumber by humanists and social scientists are big questions that the Commissioners all beg, but they also answer them immediately and positively. "Yes, we can" is their response, and the country must count upon its "educated citizens," even though those citizens ideally would have profiles more like their scholarly colleagues in the twentieth-century clerisy (Kotkin, 2014) than the everyday average commuters out on the freeways. In their document, they respond in some detail:

Who will lead America into a bright future?

Citizens who are educated in the broadest possible sense, so that they can participate in their own governance and engage with the world. An adaptable and creative workforce. Experts in national security, equipped with the cultural understanding, knowledge of social dynamics, and language proficiency to lead our foreign service and military through complex global conflicts. Elected officials and a broader public who exercise civil political discourse, founded on an appreciation of the ways our differences and commonalities have shaped our rich history. We must prepare the next generation to be these future leaders (HM, 2013:3).

To make such mystifying claims, one wonders if they understand anything about how empty civic education is today. Instead the commissioners, their directors, and their audiences, as a bloc of political true believers, appear to be "an absurdity," since their claims about liberal education could indeed be read as "the hallucinations of its death struggle, words that are reduced to phrases, spirits reduced to ghosts" (Marx, 1978: 613-614). For nearly two decades, humanists (Donoghue, 2008) and social scientists (Flyvbjerg, 2001) have been in despair about how little impact they have had in society since the 1960s. Do the report's authors know something everyone else does not or is this grand document only another academic ghost dance to conjure up lost days of yore when such learned discourses were honored and/or needed?

\section{What Matters?}

This analysis, therefore, will reconsider the apparent aspirations and stated significance of this American Academy of Arts \& Science's study (founded in 1780 hereafter AAAS in this study), The Heart of the Matter: The Humanities and Social Sciences (2013). The report's production and dissemination mimics at the national level the machinations of power, position, and privilege found on most major research university campuses. And, so too does it follow the trail blazed by the quite influential National Academies report Rising Above the Gathering Storm (2007) that was produced to bolster the importance of science and technology disciplines in society. After three years of lobbying on the basis of that earlier 2007 report with which "the scientific community has worked to strengthen education in the STEM disciplines (science, technology, engineering, and mathematics) and to encourage new and expanded funding for scientific research" (HM, 2013: 6), humanists and social scientists, who know full well that they come up second, or indeed last, at universities, national academies, foundations, and government agencies, found a few friendly backers in Congress. With charge letters from the Senate and House, then, the American Academy of Arts \& Sciences created a Commission on the Humanities and Social Sciences with this bi-partisan backing from both chambers of Congress in 2010.

The members, missions, and meanings assigned to this undertaking are fascinating on many levels. They reveal much about civic challenges at this turn in history, the complex contradictions that keep them from being overcome, and cultural continuities in the USA over the past 100 to 120 years that have both constrained a "stronger, more vibrant civil society" and downplayed the "excellence in humanities and social scientific scholarship and education" (HM, 2013: 6). Even though the Academy, its commissioners, Congress and many others putatively value such knowledge, 
might these seemingly well-intentioned, liberal democratic forces also express more rigid, if not repressive, agendas in the development of this report?

Without defining their terms, the major goals of their study are, ironically, stability-seeking, security-driven, and self-centered. Of course, science alone cannot do everything, so the humanities and social sciences must develop "a vibrant, competitive, and secure nation" (HM, 2013: cover). The professed purposes of "liberal education" then are pressed into an organized state-corporate academic plan that smacks of illiberal indoctrination, namely,

The Heart of the Matter identifies three overarching goals: 1) to educate Americans in the knowledge, skills, and understanding they will need to thrive in a twenty-first century democracy; 2) to foster a society that is innovative, competitive, and strong; and, 3) to equip the nation for leadership in an interconnected world (HM, 2013: 6).

These goals strongly reaffirm the classic Progressive agendas of the USA's corporate elites that long ago turned "American schools into a central social institution for the production of men and women who conformed to the needs of a corporate and technocratic world" (Spring, 1972: 1).

These needs remain manifest in the Commission Report: Americans must be the strategic leaders of our world; they must have an education that makes them strong, competitive, and innovative; and, American understandings, skills, and knowledges must thrive by bringing the nation's proceduralist democracy into full sway across the world during the current century. Individual freedoms, self-realization, collective liberation are not being celebrated here. On the contrary, the report's goals largely are statist, parochial, nationalistic, and technocratic. In the final analysis, the affairs of the state are so dire today that even the humanities and social sciences--along with STEM disciplines-must be mobilized in the name of the nation's security, competition, and vibrancy. At the heart of these matters today, not unlike 50 years ago, "public safety seems to many Americans to require increasingly repressive measures on the part of the state whose powers have already dangerously expanded, and which finds itself inextricably involved in similar police actions abroad" (Lasch, 1966: 30).

Since the founding of the American Council of Learned Societies in 1919 during the aftermath of World War One, the policing of academic disciplinary boundaries, mission statements, and social purposes has been a recurrent worry among American academics (Mills, 1951; Ricci, 1987; Oren, 2013; and, Kotkin, 2014). Recognizing their essentially subaltern, if not marginal, status in an unabashedly industrial capitalist order that celebrates commerce and cash over concepts and collegiality, many liberal arts disciplines in the USA have been searching for acceptance and significance in the new industrial state by showing what their individual intellectual vocations might bring to the table for life, liberty and the pursuit of happiness. Official commissions, which are struck by municipal, state or national authorities, provide good recurrent opportunities for announcing such "discoveries," and this recent appeal to the AAAS to launch a National Commission on the Humanities and Social Sciences in 2011 is no exception. Since humanities and social science faculties often are being either administratively shunned, or sliced down to near nothing, on campus, their academic leaders want to wave formal documents like this one in front of deans, provosts, and presidents in attempts to prove they are still needed or maybe even valued.[1]

The Heart of the Matter, ironically, is then an intricate map of another new human terrain to be engineered systematically during the still long, and not much forgotten, global war on terror (GWOT). After twelve years of inconclusive, if not failed, war-making in the Middle East, the humanities and social sciences are mobilized in this report to maintain stability and consensus at home by anchoring the Republic's continued need "to connect us with our global community" (HM, 2013:9) and thereby guarantee "the success of cultural diplomacy in the 21st century" (HM, 2013: 6). While anthropology and psychology have been compromised during the big battles of this on-going GWOT in Southwest Asia, as behavioral and social science was in Southeast Asia during the shooting war against Communism five decades ago, these AAAS Commissioners explicitly are arguing human progress in liberal capitalist democracy needs the constant care and astute attention of social science to keep the American Republic on its rails.

Connecting with the global community, particularly as the anchor of "the West" standing resolutely against a host of nondemocratic, undeveloped, and anti-capitalist competitors, requires some modicum of domestic cultural capital, political tradition, and economic literacy that most only get from their humanities and social sciences at school. With more humanities and social sciences lessons, therefore, the report presumes the most positive possible outcomes will be assured. Otherwise, what will the global community want to emulate in America? The humanities and social sciences purportedly will keep these intangible intellectual and moral assets viable, and the USA will still remain competitive as a global model for attaining "the good life." 


\section{Where is the Heart?}

The letters of invitation proposing to convene the Commission from the U.S. Senate and House of Representatives, which were signed respectively by Senator Lamar Alexander (R)-Tennessee and Mark R. Warner (D)-Virginia plus Congressmen David Price (D)-North Carolina and Thomas E. Petri (R)-Wisconsin, were issued on September 27 and December 6, 2010. Interestingly enough, the Occupy Wall Street movement took hold on the busy streets of Lower Manhattan about a year later. On September 17, 2011 after Kalle Lasn and Micah White from Adbusters registered the www.Occupy/WallStreet.org address in the spirit of getting the USA "its own Tahrir," a loose national movement of social activists, civic groups, and unemployed people to follow the citizenship-in-action examples set by Egyptian activists in the occupation of Tahrir Square on January 25, 2011.

After selecting One Chase Manhattan Plaza and Bowling Green Park as prime venues, the OWS groups ended up settling in Zuccotti Park, once preemptive police actions blocked the first two locations. Although the occupation there lasted only about two months, it vividly marked one example of citizens engaged in democratic decisionmaking based on "a shared knowledge of history, civics, and social studies" which The Heart of the Matter report entreated the nation to support (HM, 2013: 10). Of course, this popular participatory engagement in democratic processes is not mentioned in the Commission's report in any manner whatsoever, because the Report appears to aim its humanities and social science teaching at the white-collar elites running Wall Street instead of the citizens in the park protesting against the 1 percent working in the Wall Street banks and brokerages near Zuccotti Park.

Civic incidents and political movements, like 2011's Occupy Wall Street rallies or the "9/12 Tea Party" Taxpayer March on Washington in September 2009, exceed the passive participant subjectivity so favored by mainstream American democratic theory since the 1950s. This narrow construction of capitalist liberal democracy is quite limited inasmuch as it intellectually, legally, and politically admits that it only generally "allows citizens to participate meaningfully in the democratic process--as voters, informed consumers, and productive workers" (HM, 2013: 10). Organizing on the street by many ordinary people, as a democratic mass public, does not match that profile of preferred political agency--so it is ignored.

The 53 members who served on the Commission were a select group that one maybe would imagine should favor having a "stronger, more vibrant civil society." Yet, their distinguished qualities betray an extreme narrowness in perspective, displaying how brittle and stressed America's civil society is. Not surprisingly, many are academics, and with few exceptions, they also are based in private and wealthy universities--Princeton (three members), Washington University, Harvard (three members), USC, Pennsylvania, Stanford (two members), Duke, Notre Dame, Amherst, Cornell, Miami, Johns Hopkins, NYU, Texas, George Washington along with a few from public schools--CaliforniaBerkeley, Texas, and Miami-Dade Community College. Some professors served, but college presidents, chancellors, and deans were more numerous. Some elite law firms, museums, libraries, and philanthropic organizations were represented, but major corporations were also represented quite prominently--Exelon, Lockheed Martin, TIAACREF, Boeing, Skywalker Properties, and Adobe Systems. A few relatively well-known artists--Ken Burns, Emmy Lou Harris, John Lithgow, and Yo Yo Ma--were participants as well as less famous journalists and judges.

The American Academy for the Arts \& Sciences also was joined in this effort by the Association of American Universities (AAU), American Council of Learned Societies (ACLS), and The National Endowment for the Arts (NEA), National Academy of Engineering (NAE), National Academy of Sciences (NAS), The New York Times, National Gallery of Art, and The Smithsonian Institution. Politically, the Commission had a former Ambassador to Afghanistan and former Governor of Tennessee plus a retired Supreme Court Justice and former Congressman. While the Commission featured literary scholars, poets, historians, musicians, law professors, humanists, churchmen, and communication scholars, it also enlisted prominent political scientists and theorists--Danielle S. Allen (Institute for Advanced Study), Kwame Anthony Appiah (Harvard), Amy Guttmann (Pennsylvania), and Donna E. Shalala (Miami). Gutman and Shalala also were sitting presidents of their universities. A fair number of engineers, economists, scientists, businessmen, and lawyers rounded out the mix; but, this small group of privileged elite individuals is employed mostly in professions linked to education, culture, law and government, which is far from a broad cross-section of American civil society.

Representatives from AAU and Ivy League schools dominated the university contingent; only one community college and one "selective liberal arts college" were invited. The clear implication is that "leaders equipped for an interconnected world" do not come from just any regional public university or small college. They would be recruited instead, like the members on this commission, from more refined worlds of intellectual interconnection. 
The Commission held six fora around the nation, including Cambridge, MA; Stanford, CA; St. Louis, MO; Miami, FL; Durham, NC; and New York, NY to listen to a mix of voices from varied institutions, less visible schools, and different people, but the study itself was truly an AAAS product with 47 of 53 Commission members being AAAS Fellows, including its two co-chairs. Out in the six regional fora, the cast of characters was equally elitist.

Looking through the lists, it would appear not more than seven--a librarian in New England, a then current Stanford undergraduate, a US Marine sergeant who graduated at Stanford in 2012, an Eastern Shawnee Indian chief from Oklahoma, a bookstore owner in Miami, an assistant high school principal in Durham, NC, and a young playwright in New York City--could be called something like the "ordinary citizens" that humanities and social sciences are meant to make into truly enriched souls and solid citizens. Hence, this compact carnival of nationally known humanists, social scientists, politicians, and other public figures became a nomadic band of lobbyists pushing their special bill of recognition across the country to reaffirm their vocational purpose and collective utility to their countrymen and the nation's higher authorities.

At the six for a around the nation, the list of participants and where they convened does not suggest a major effort was made to break out of an equally elite envelope of well-positioned institutions and individuals. Four of the six for a were held in metropolitan areas with regional Federal Reserve Banks--San Francisco, St. Louis, New York, and Boston. And, former state governors, US Supreme court Justices, US Secretaries of State, major corporate CEOs, chairpersons of big charitable trusts, and smatterings of local professors, artists, K-12 educators, museum directors, writers, and arts council representatives came for a day of discussion in these major commercial hubs as well two other sessions--one in Durham, North Carolina and another in Miami, Florida. The Commission's message was laced with the classic Progressive elite's hopes to mobilize the humanities and social sciences to anchor a liberal education for all citizens. Still, very few ordinary citizens appear to have been invited "to reveal those patterns in the lives of real people" (HM, 2013: 17). Of course, one can claim that this whole cast of characters are "real people," but they plainly are far more real than the ordinary guys and gals who putatively need more humanities and social sciences to spice up their hum-drum everyday lives.

\section{A Torn Heart?}

The formation of commissions, like this AAAS body asked to report on the utility of the humanities and social sciences for the Republic and its citizens, is also in some ways demeaning. This Commission's framing statement misconstrues the importance of such knowledge as being little more than workforce training assets, civic preparedness instructions or globalization acceptance exercises. Corporate elites are, or have been convinced, about the merits of such learning for at least key elements in the striving upper middle class. Once again, these Commissioners were ratifying the importance of the same goals touted for over a century in the USA for themselves, the Commission, and the business elites who back their efforts. Many comparable commissions have been organized, made reports, and popularized their findings for at least as long as the social sciences have been organized in their current disciplinary configurations (Cook, 1910). A few recommendations made by such bodies have been followed, but most reports have been left sitting on the back shelves of dimly lit library stacks unknown and unread -- until the next monumental effort a decade or two later that comes the same conclusions.

At the current political conjuncture today, however, unwanted and unintended side effects also are complicating these traditionally honorific assignments: a division among business elites about the merits of higher education itself, a fixation upon job readiness over civic awareness, and a rising distrust in all science itself. Doubts about organized social science have been with us in the USA since Senator William Proxmire's (D)-Wisconsin "Golden Fleece” awards from 1975 to 1988 for frivolous spending on apparently silly studies. The efforts of latter-day prairie penny-pinchers, like Senator Tom Coburn (R)-Oklahoma or Congressmen Larry Dean Bucshon (R)-Indiana and Lamar S. Smith (R)Texas, however, are more radical. They intend to curtail, cut or entirely close National Science Foundation funding, first, for the social sciences and then natural sciences they find "useless." This intense level of antiscientific beancounting "know nothingness" is something new. Whether it is climate change science, new antibiotic drug research, field biology studies of endangered species, support for childhood vaccinations, environmental science surveys of mountain top removal mining, fossil fuel fracking or ethanol production, partisan disinformation campaigns by the religious right, industry lobbies or Tea Party libertarians have become aggressively dismissive of science itself as well as much of "the knowledge" it produces.

Four generations after the APSA was organized by bureaucrats, politicians, and social scientists at the turn of 
the twentieth century, its membership--along with those signed up as members of the MPSA, NEPSA, SPSA, and WPSA--are enjoined frequently to call, e-mail or write their Congressional delegations to protect the discipline's continued intellectual legitimacy--as marked by continued funding for scientific research by the NSF.[2] Many of those in Congress who push these programs claim the money would be better spent on STEM-related research or new medical science; but, such justifications are disingenuous. Many of their backers and allies, if not the politicians themselves, also dispute the findings of climatologists, do not allow their children to get vaccinations against common pathogens, and dismiss the responsibility of the nation to care for the poor, infirm and aged even with such minimal public health insurance schemes as Obamacare.

To a very real degree, one must ask if The Heart of the Matter is, at best, the last gasp of civic Progressive education in a failing state or, at worst, another indicator of the elite's evidently pathetic cluelessness about today's extreme ideological crisis. That is, do the nation's citizens and elites, in fact, want to lead today's interconnected world, value competitive innovation, or seek the knowledge, skill and understanding of a twenty-first century democracy? Arguably, many do not, and they recognize, more easily than most academicians, corporate managers, artists or legal experts, that neoisolationism, protectionism, and quietism better suit the oligarchical plutonomy that has grown in strength within the USA since the late 1970s (Luke, 2011).

The ostensible civic-mindedness of this AAAS Commission Report, moreover, is also at odds with other white papers from organizations like the American Council on Education (ACE). This group is calling into doubt the putatively privileged role of faculty in higher education (ACE, 2014a) as well as the basic business model of higher education itself (ACE, 2014b). Funded by grants from the Bill and Melinda Gates Foundation, the American Council on Education has pulled together a number of university and college presidents to think about higher education in a group named the Presidential Innovation Laboratory (PIL). The openly corporate centered agenda of the Gates Foundation is evident in its assault on traditional "faculty roles" and outmoded "college business models."

Excited about the prospects for using more technology for teaching and learning, PIL is called for "a renewed focus on faculty roles" (ACE, 2014a). Needless to say, this model of instruction strays some distance from the traditional faculty roles of "working with students on moral development" (ACE, 2014a) as one might expect from a strong renewal of humanities and social science education. Without this anchor in strong university-level faculties, it is also unclear how the reintroduction of better humanities and social science education could work its way into K-12 education or focus on the international competitiveness of American businesses and government services.

The unbundling of university and college faculty roles, moreover, would truly be accelerated by shifting the "business models" of higher education to pay for providing different curricula aimed at more directly marketable skills to student populations continuously aggregated out of the vocational needs found in different age cohorts (ACE, 2014b). The need for humanities and social science learning is never-ending; but, if it never starts, due to the total domination vocationally structured curricula and STEM-centered institutional practices in schools, then the prospects for bringing these other forms of knowledge to bear for creating a more secure, competitive, and vibrant nation will largely be lost. On these counts, it appears that the Bill and Melinda Gates Foundation would not see greatly reduced humanities and social sciences teaching capacities as a crippling loss either to higher education or to its students wending their ways into the work force.

Instead, like other right-wing reformers, from ALEC to ACTA, the Gates Foundation seems to regard humanities and social science education as unwanted historical leftovers that now amount to the less and less that is relevant to the education of the twenty-first century workforce. Indeed, they are dead weight or disabling drag on the hull of reform, preventing swift passage of STEM-centered learning to the top of all institutions' "to-do" lists. At best, then, the humanities and social sciences are likely to be cut adrift by such reforms to float away on the murky waters of "general education," while the enduring ideals of liberal education are simply left to sink out of sight.

\section{The True Heart of the Matter = HASSLE}

The Commission's statement that "the strength of a republic depends on the ability of its citizens to participate fully in decision-making processes. . by making informed decisions as voters, jurors, and consumers” (HM, 2013: 24 ) is a pious platitude, which many trends in American society work hard to paralyze. While the American education system may have been once focused on preparing K-12 students for "full participation in a democratic society" (HM, 2013: 24), oligarchical elites, negotiated legal settlements, and predatory corporations now are putting major roadblocks in the way of full citizen participation in campaigns and elections, jury trials, and rational informed 
consumption.

In an educational system intoxicated by STEM initiatives, the humanities and social sciences are believed to have little apparent market utility. Their subject matter, instructors, and avowed purpose are either demeaned or ignored by the powers that prevail in America's liberal capitalist democracy. Those in power wish to stay in control, and few really want to confront "a broadly educated, well-informed, articulate citizenry" (HM, 2013: 24). Hence, civics is reprocessed as American history, reduced to formalistic rote principles or simply eliminated as local school boards and parents push for new instructional plans that focus almost exclusively on STEM-based workforce preparation skills. Like art, music, physical education or recess, civics is being recast as "a nicety" rather than "a necessity."

Common baseline competencies in history, government, and ethics are not being actively debated or developed; and, when they are, school administrators and teachers often run afoul of push-back from fundamentalist religious reactions, right-wing media ridicule or ruthless corporate rejections of such skills. Everyone must work, but should, could or would everyone participate in public life? Many detractors question this goal, do not want to see it happen, and, in fact, deny educators the time and resources to cultivate "the competencies necessary for full civil participation in American society: voting, serving on juries, interpreting current events, developing a respect for and understanding of differences, along with an ability to articulate one's sense of the common good" (HM, 2013: 24). These are complex and conflictual skills that require dissent, doubt, and disputation to operate effectively, but the Report's authors downplay those inescapable realities. The humanities and social sciences are critical for the liberal education needed to cultivate and keep freedom as a lived personal experience and shared collective value, but these necessities rarely are attained nicely.

While everyone is eager to affirm the centrality of STEM education for the nation, who sincerely recognizes the significance of gathering the "Humanities and Social Sciences for Liberal Education," or if you will "HASSLE," to sustain the Republic's development? Real teaching and learning require honest and tough training in the techniques and goals of fomenting a rich civic life, which should accept that democratic governance runs, in part, on the conflict, contradictions, and clash of opposing interests. To be free is also to be engaged in perpetual "hassles." Liberal education is about freedom, and being free will always necessarily involve conflict, a burden, challenge, a dissensus, and contradiction. These struggles, as James Madison and John Stuart Mill recognized, are what fulfill the promise of freedom, self-determination, and collective decision-making. Without HASSLE-based learning, liberal democracy fails, just as competitive technological economies wither in the absence of rigorous STEM-oriented training.[3] And, plutonomic elites value their STEM-driven assets far more than liberal democracy and its hassles. Indeed, a HASSLE-free society, for many among the top 1, 5 or 10 percent of society, is much preferred over a HASSLE-centered educational system, civic life, and national competitiveness.

That the USA has slipped behind other major economies, key allies or potential adversaries over the last 35 40 years should be no surprise. Few localities, state leaders or national authorities--despite sanctimonious studies like The Heart of the Matter--want to embrace HASSLE-driven teaching and learning as the nation spins further into poverty, weakness and insignificance, because HASSLE-trained citizens would decry these failures. Today, it is STEM "that matters," and HASSLE is, quite literally, regarded as "too much hassle" for late capitalist subjects to handle. Voices in the power elite continue affirming the importance of HASSLE, but actions taken by this same bloc of social forces does everything to make humanities and social sciences more and more inconsequential in the education, commerce, and administration of allegedly liberal capitalist democracies that are increasingly illiberal mercantile oligarchies (Kotkin, 2014).

In fact, another interpretation is that these elite educationalists are not interested that much in creating more real democracy. They are comfortable with a high level of mass aliteracy, civic disengagement, and social anomie. These incapacitating qualities permit "the public" to be much better served by liberal education's real target audience of upper middle class academic strivers, aspiring to gain entrance to the technostructure, corporate elite, state clerisy or cultural spotlight. This is the true crisis: humanities and social science have been derided or destroyed so extensively that even elite institutions, whose students need this knowledge, are now disserving their elite clientele. Progressiveleaning elite individuals do favor training "the right people" who should rule over, care for, or minister to "the people" as the wards of such refined technocratic demoligarchs rather than the constituents of merely elected crass democrats. The flows of capital, information, energy, and labor in global fast capitalism require special treatment, and those few strands of the HASSLE traditions that survive the next generation might only be pitched to speak to, for, and about the "kineformative kultur" of global capitalist exchange (Luke, 2005). To be caring and cautious, these Davos-minded global elites, in fact, do need good humanities and social science knowledge to glue together the class 
fractions and their powers for the ruling blocs of their plutonomy.

Embracing HASSLE in the humanities and social sciences as a watchword for engagé scholarly focus, then, has a certain insouciant, if not provocative, quality. For some, a hassle is some activity that is not worth the difficult effort involved in doing it. STEM fetishists will betray themselves immediately by acknowledging humanities and social science learning is far too difficult for them--since "it's a hassle"--to exert any effort at mastering its complexities as they content themselves with STEM's putative mathematical elegance and simplicities.

More astute defenders of liberal education will immediately hear strains of John Stuart Mills' On Liberty, the French Encyclopedists' Deistic secularism or militant anarchism's quest for human emancipation in recognizing no truth or error is truly known without multiple troublesome confrontations with error or truth. Coming to full flower through humanistic learning as personal Bildung actually requires much bother, annoyance and trouble to actualize all of humanity's tragic and sublime potentialities. Moreover, the purposive troubling of settled unquestioned domination, routine or prejudice makes everyone more alive, conscious, and engaged by learning. One should best remain alertly unsettled than being ineptly settled. Humanities and social sciences are about individuals and societies, and many recognize not all is right for the people alone and in groups. For all these reasons, HASSLE is plainly needed.

Picking the right argument, starting the good fight, and initiating the needed annoyance, and spending the required time to be bothered are crucial. HASSLE is worth any hassle, and its values are most often realized by causing bigger hassles. The Commission shrinks from pushing this truth very hard in their project, so the HASSLE they pretend to defend must only root out systemic problems caused by the complex pressures of money, information, time or inconvenience. At their best, knowledge from the humanities and social sciences will free people, enlarge the ambit of substantive freedom, and move social practices to new ground, while providing better understandings of all that is in play. Implicitly this could be what the commissioners want, but the tepid establishmentarianism of their findings barely rise above glib ideological mystification. Ironically, the putative champions of HASSLE will not even get into a truly major hassle to defend HASSLE.

Contesting the hegemony of STEM, or its allegedly more engaged STEM-H, in society, education and academe will always be a major hassle, but HASSLE is well-worth every annoyance, bother or conflict down this road. Yet, there are no guarantees in today's ambivalent conditions. On the one hand, HASSLE-centered learning could recharge the slumbering masses in a truly democratic awakening, which some feared in Occupy Wall Street. Meanwhile, on the other hand, HASSLE-driven teaching could be made more available to the guardians working on and with Wall Street so that they might more gracefully guide a caring state, the open society, a diverse culture, and the plutonomic economy.

\section{| Bending STEM, Pushing HASSLE}

The Heart of the Matter is a fascinating ideological text that invokes the importance of humanistic and social scientific education without any mention of decisive recent public events-from the build-up to the dotcom bust to the invasion of Iraq to the unraveling of Central America--in which such knowledge has been so sorely missing. Even though the report explicitly states "the views expressed in this volume are those held by the contributors and are not necessarily those of the Officers and Fellows of the American Academy of Arts and Sciences” (HM, 2013: 3), the contributors and the AAAS fail themselves and the nation in this report. They fall back from pushing hard to highlight HASSLE, and instead accept the traditional underworker status of the humanities and social sciences to STEM disciplines. Sensing a horrendous lack of literacy, rising civic unpreparedness, growing unawareness of vital texts, and spreading public disengagement, they push platitudes. At the bottom line, all students should get a little remedial help, but the elite few will be redeployed to advance their putative rededication to engaging the public, increasing access to online resources, investing in civic education, and supporting full literacy (HM, 2013: 10) to bolster the nation's moral fiber and civic timber.

After 30 years of global war on terrorism, the end of the Cold War, three inconclusive wars in the Middle East and Southwest Asia, the collapse of the Soviet Union, and decades of economic stagnation, this AAAS Commission superficially endorses anodyne treatments for the nation's intellectual and moral deficits. But, it eagerly specifies how such treatments should be administered by the well-educated elite clerisy (Kotkin 2014). This agenda meets their topline goals by outlining an elaborate program of investments and engagements for the humanities and social sciences at "The Best Colleges and Universities." As they recycle common criticisms of shortfalls, gaps, and deficits that 
have been recognized since the early days of the Space Race in the late 1950s when the decay of humanities and the social sciences obviously took root, the Commission's secondary and tertiary goals read like a wish list of pork for resource-starved and recognition-deprived elite academicians, including

- Increased investment in research and discovery

- $\quad$ Creating new curricula to anchor basic competencies

- Strengthening support for teachers

- Encouraging all disciplines to help all obtain clean air, safe water, adequate food, good health, sufficient energy, and universal education

- Communicate the importance of research to mass publics

- Promote language learning

- Expand international education support study abroad and international exchanges

- Develop a Culture Corps to educate the public

(HM, 2013: 11-13)

Asserting these initiatives “are critical to our pursuit of liberty, and happiness, as described by our nation's founders. They are The Heart of the Matter" (HM, 2013: 13), the report then lays out a strange case--not unlike our Federalist Founding Fathers--for continuing humanistic and social scientific education for "the right people" striving above and apart from most citizens. This enlightened elite then could grapple with the gritty challenges of managing a capitalist economy, ruling a complex state or coping with a conflicted civil society.

Indeed, one can read their arguments as a self-interested ploy to celebrate the importance of the most select humanities and social science centers, since they are among the elite few in the top echelon of liberal arts based universities who actually try to master these disciplines. These degrees also are cash cows in many academic enterprises, and their institutions' books will stay better balanced to the extent that they can admit many more humanists and social scientists to subsidize the output of far more expensive STEM graduates. Any new infusion of HASSLE-tagged monies from foundations or states also are likely to be diverted to these supposedly worldclass producers of humanists and social scientists as opposed to less visible regional training sites, like Chico State University, the University of South Dakota, University of Texas-Arlington, Indiana State University or Virginia Tech, which are regarded as training swarms of worker bees and drones for the corporate world. In other words, at The Heart of the Matter, one strangely hears this new class elite singing, like Devo in the 1970s, "we are the Culture Corps." And, they want--in a very comparable devolutionary manner--to secure American society's blessings to train more of themselves "to educate the public" whose many members apparently require this elitist "corps cultural" education in their humanities and social sciences to keep them in their progressively proper places.

The Heart of the Matter is a fascinating ideological text. Written during a decade of war against, in part, radical Islamist fundamentalism, Ba'athist authoritarianism, and antimodern quasi-criminal rebels, it speaks for bigger and better educational efforts in the humanities and social sciences purportedly to help the public better understand the crises of the day tied to such existential threats. Yet, it also "speaks to" the public about their need to endure being guided by a "cultural corps," instructing them about how and why "the best and brightest" require such learning. The heart of the matter then is serving the interests of this entrenched academic clerisy and sustaining their leadership of the people as a body politic of flexible citizens called upon to adapt to neoliberal competition, transnational values, and perhaps permanent war.

\section{Endnotes}

1. In this context, one also must be mindful of how liquid modernity's informatics flows are eroding all modes of scholarly activity and communication. On this shift, see Wouters, Beaulieu, Schamhorts, and Wyatt (2012).

2. These are the official organizations of political science as a discipline in the USA national and regionally: American Political Science Association (APSA),
Midwest Political Science (MPSA), Northeastern Political Science Association (NPSA), Southern Political Science Association (SPSA), and Western Political Science Association (WPSA).

3. Here HASSLE flows along as the Humanities and Social Sciences for Liberal Education. A friendly amendment in another context would change the " $A$ " 
to "Art," or Humanities, Arts, and Social Sciences for Liberal Education lest we let STEM coopt the Arts as STEAM: Science, Technology, Engineering, Arts, and Mathematics.

\section{References}

*An earlier version of this paper was presented at the annual meetings of New Political Science Section, the American Political Science Association, August 28-31, 2014.

American Academy of Arts \& Sciences. 2013. The Heart of the Matter. Cambridge, MA: AAAS.

American Council on Education. 2014a. "Presidential Innovation Lab-Unbundling versus Designing Faculty Roles.”

American Council on Education. 2014b. "Presidential Innovation Lab-Beyond the Inflection Point: Reimaging Business Models for Higher Education."

Arum, Richard and Roksa, Josipa. 2010. Academically Adrift: Limited Learning on College Campuses. Chicago: University of Chicago Press.

Callahan, Raymond E. 1962. Education and the Cult of Efficiency. Chicago: University of Chicago Press.

Cook, Morris. 1910. Academic and Industrial Efficiency: A Report on the Carnegie Foundation for the Advancement of Teaching. New York: Carnegie Foundation.

Dewey, John. 1963 [1935]. Liberalism \& Social Action. New York: G. P. Putnam \& Sons.

Dewey, John. 1954 [1927]. The Public \& Its Problems. Chicago: Sage Books/The Swallow Press.

Donoghue, Frank. 2008. The Last Professors: The Corporate University and the Fate of the Humanities. New York: Fordham University Press.

Flyvbjerg, Bent. 2001. Making Social Science Matter: Why Social Inquiry Fails and How It Can Succeed Again. Cambridge: Cambridge University Press.

Ginsberg, Benjamin. 2011. The Fall of the Faculty: The Rise of the All-Administrative University and Why It Matters. Oxford: Oxford University Press.

Kotkin, Joel. 2014. The New Class Conflict. Candor, NY: Telos Press Publishing.

Lasch, Christopher. 1966. The Agony of the American Left. New York: Knopf.
Luke, Timothy W. 2011. "Blow Out, Blow Back, Blow Up, Blow Off: The Plutonomic Politics of Economic Crisis Since 2001," Fast Capitalism, 8.2 http://www.fastcapitalism.com

Luke, Timothy W. 2005. "Scanning Fast Capitalism: Quasipolitan Order and New Social Flowmations," Fast Capitalism, 1.1 http://www.fastcapitalism.com

Marx, Karl. 1978. "Economic and Philosophic Manuscripts of 1844," The Marx-Engels Reader, ed. Robert C. Tucker, second edition. New York: W. W. Norton.

Marx, Karl. 1978. "The Eighteenth Brumaire of Louis Bonaparte," The Marx-Engels Reader, ed. Robert C. Tucker, second edition. New York: W. W. Norton.

Noble, David E. 1977. America by Design: Science, Technology, and the rise of Corporate Capitalism. New York: Knopf.

Oakeshott, Michael. 1989. The Voice of Liberal Learning: Michael Oakeshott on Education, ed. Timothy Fuller. New Haven, CT: Yale University Press.

Oren, Ido. 2013. Our Enemies and US: America's Rivalries and the Making of Political Science. Ithaca: Cornell University Press.

Ricci, David. 1987. The Tragedy of Political Science: Politics, Scholarship, and Democracy. New Haven, CT: Yale University Press.

Spring, Joel H. 1972. Education and the Rise of the Corporate State. Boston: Beacon Press.

Veblen, Thorstein. 1905 [1918]. The Higher Learning in America: A Memorandum on the Conduct of Universities by Businessmen. New York: A. M. Kelley.

White, Morton. 1957. Social Thought in America: The Revolt Against Formalism with a New Preface and an Epilogue. Boston: Beacon Press.

Wouters, Paul, Beaulieu, Anne, Scharnhorst, Andrea, and Wyatt, Sally. 2012. Virtual Knowledge: Experimenting in the Humanities and the Social Sciences. Cambridge, MA: MIT Press. 